\title{
Harmonizing The Doctrines Of Enablement And Obviousness in Patent LITIGATION
}

\author{
By Roy D. Gross*
}

Volume XII - Spring 2012

\begin{abstract}
This Article examines the balance between advancing one's arguments that a patent is invalid for lack of enablement and also arguing that a patent is invalid under 35 U.S.C. $\S 103$ as being obvious over the prior art. This is significant with regards to arguments made by an expert in his or her expert report or at trial. A clear litigation strategy is thus recommended prior to reaching the expert report stage in a patent litigation.
\end{abstract}

\footnotetext{
* Associate at St. Onge Steward Johnson \& Reens, Stamford, Connecticut. Benjamin N. Cardozo School of Law, J.D., with a concentration in Intellectual Property 2007; Massachusetts Institute of Technology, B.S. in Chemical Engineering 2004. The opinions expressed in this article are the author's alone and should not be attributed to St. Onge Steward Johnson \& Reens or its clients.
} 


\title{
Harmonizing The Doctrines Of Enablement And Obviousness in Patent LITIGATION
}

\author{
By Roy D. Gross
}

Volume XII - Spring 2012

\section{INTRODUCTION}

In order for a patent to be valid, one of the requirements of U.S. patent law is that it must meet the enablement requirement. As provided by 35 U.S.C. $\S 112$, first paragraph, "[t]he specification shall contain a written description of the invention, and of the manner and process of making and using it, in such full, clear, concise, and exact terms as to enable any person skilled in the art to which it pertains, or with which it is most nearly connected, to make and use the same."

In the context of patent litigation, recent Federal Circuit opinions have found certain patents to be invalid for lack of enablement. ${ }^{2}$ These opinions have suggested that lack of enablement is becoming a powerful tool used by Defendants to invalidate patents. ${ }^{3}$ However,

\footnotetext{
${ }^{1} 35$ U.S.C. $\S 112(1975)$.

${ }^{2}$ See AK Steel Corp. v. Sollac, 344 F.3d 1234 (Fed. Cir. 2003) (holding that while the specification only teaches Type 2 aluminum, the claim scope covers Type 1 aluminum and thus the claims are not enabled); see Sitrick v. Dreamworks, L.L.C., 516 F.3d 993 (Fed. Cir. 2008) (holding that claims that encompass both video games and movies were invalid for lack of enablement as specification did not disclose a reference to movies); see LiebelFlarsheim Co. v. Medrad, Inc., 481 F.3d 1371 (Fed. Cir. 2007) (holding that the patent claims were invalid because the disclosure must teach the full range of embodiments in order for the claims to be enabled, and here the disclosure did not teach the pressure jacket, which was an embodiment of the invention). See Auto. Techs. Int'l, Inc. v. BMW of N. Am., Inc., 501 F.3d 1274 (Fed. Cir. 2007) (providing that claims that include mechanical side impact sensors and electronic side impact sensors were invalid as only mechanical side impact sensors were taught by specification); see Plant Genetic Sys. v.DeKalb Genetics Corp., 315 F.3d 1335 (Fed. Cir. 2003) (holding that claims for "a plant cell" where specification only taught dicot plants and not monocot plants were invalid as undue experimentation was required for monocot plants); and see In re Vaeck, 947 F.2d 488 (holding that broad claims directed to cyanobacteria were invalid as only one species of cyanobacteria is employed in the working examples of specification.

${ }^{3}$ See AK Steel Corp., 344 F.3d 1234 (holding that claims are invalid for lack of enablement and refusing to address inquiries related to anticipation based upon prior art). See also Audrey A. Millemann, Lack of Enablement - A
} 
there is a disconnect between advancing one's arguments that a patent is invalid for lack of enablement under 35 U.S.C. $\S 112$ and also arguing that a patent is invalid under 35 U.S.C. $\S 103$ as being obvious over the prior art, in that arguing that a patent is invalid for lack of enablement typically cuts against arguments that a patent is obvious over the prior art, and vice-versa.

This article examines the delicate framework between promoting one's arguments that a patent is invalid, while maintaining the ability to preserve one's obviousness arguments in the alternative. This conundrum is especially significant during pre-trial case development, particularly when drafting expert reports and invalidity contentions. Both expert reports and invalidity contentions are typically drafted to be expansive and to preserve all possible arguments to be made by a party. Similarly, during pre-trial expert depositions, experts often are forced to take certain positions about prior art and knowledge in the art, which may cut against future arguments made at trial. ${ }^{4}$ In this context, it is often contradictory and problematic for an expert to take a position that a patent specification does not enable the patent claims in light of the elements that are known in the art, while also simultaneously arguing that the same known elements may be used to invalidate the patent under $\S 103$ as being obvious. ${ }^{5}$

Part I of this Article examines the enablement standard in light of recent Federal Circuit opinions. Part II provides a brief overview of the inherent dilemma between simultaneously advancing an argument that a patent is invalid for lack of enablement, while also arguing that a patent is invalid as being obvious over the prior art. Part III reviews problems faced by defendants and their experts when forced to argue simultaneously that a patent is both invalid for

Stronger Tool for Invalidity, THE IP LAW BLOG (June 4, 2008), http://www.theiplawblog.com/archives/-patent-lawlack-of-enablement-a-stronger-tool-for-invalidity.html.

${ }^{4}$ See infra Part III.

${ }^{5}$ Regents of University of Cal. V. Monsanto Co. 2005 WL 3454107, *19 (N.D. Cal 2005) (refusing summary judgment on enablement as there was a material issue of fact due to contradictory expert testimony); see also Eli Lilly \& Co. v. Actavis Elizabeth L.L.C., 676 F.Supp. 2d 352 (D.N.J. 2009), aff'd in part and rev'd in part, 435 Fed. Appx. 917 (Fed. Cir. 2011). 
lack of enablement and obvious over the prior art. Finally, Part IV of this Article provides suggestions as to litigation strategies and provides a framework for defendants to simultaneously advance both their enablement and obviousness arguments.

\section{The Enablement Standard In Light Of Recent Federal Circuit Opinions}

Patent law requires that the patent applicant disclose the invention to the public in exchange for the right to exclude others from practicing the invention. ${ }^{6}$ This is known as the quid pro quo of the patent system, whereby an applicant discloses to the public his or her invention, while being granted a patent, which allows the inventor to exclude others from practicing the invention. $^{7}$ The right to exclude others and the boundaries of the exclusion are determined by the patent's claims. ${ }^{8}$

As part of the quid pro quo of the patent system, the enablement requirement helps to ensure that the boundaries of the exclusion are not improperly set or are broader than the disclosure provided to the public. ${ }^{9}$ Enablement requires that that the claims (the subject matter that is excluded from the public) be enabled "throughout their full scope without requiring undue

\footnotetext{
${ }^{6}$ Pfaff v. Wells Elecs., Inc., 525 U.S. 55, 63 (1998) (“[T]he patent system represents a carefully crafted bargain that encourages both the creation and the public disclosure of new and useful advances in technology, in return for an exclusive monopoly for a limited period of time."). See also Kewanee Oil Co. v. Bicron Corp., 416 U.S. 470, 48081 (1974) (explaining that adequate and full disclosure ensures that the public will benefit from the exclusory right). ${ }^{7}$ AK Steel, 344 F.3d at 1243. See In re Wright, 999 F.2d 1557, 1561 (Fed. Cir. 1993). See United States Patent and Trademark Office, Manual of PATENT Examining Procedure 2164.08 (8th ed. 2001), available at http://www.uspto.gov/web/offices/pac/mpep/documents/2100 2164 08.htm (last visited Mar. 31, 2012) [hereinafter MPEP] ("All questions of enablement are evaluated against the claimed subject matter. The focus of the examination inquiry is whether the substantial scope of the claim is enabled. Accordingly, the first analytical step requires that the examiner determine exactly what subject matter is encompassed by the claims.").

${ }^{8}$ Markman v. Westview Instruments, Inc., 517 U.S. 370, 373 (1996) ("[A] patent includes one or more 'claims,' which'particularly poin[t] out and distinctly clai[m] the subject matter which the applicant regards as his invention"”). See also Phillips v. AWH Corp., 415 F.3d 1303, 1312 (Fed. Cir. 2005) (holding that "[i]t is a "bedrock principle' of patent law that 'the claims of a patent define the invention to which the patentee is entitled the right to exclude."” (quoting Innova/Pure Water, Inc. v. Safari Water Filtration Sys., Inc., 381 F.3d 1111, 1115 (Fed. Cir. 2004))).

${ }_{9}^{9}$ See LizardTech, Inc. v. Earth Res. Mapping, Inc., 424 F.3d 1336, 1344 (Fed. Cir. 2005) (describing enablement as the essential part of the patent bargain).
} 
experimentation by those having ordinary skill in the art." ${ }^{10}$ In other words, "the [patent] specification must teach those of skill in the art how to make and how to use the invention as $\underline{\text { broadly }}$ as it is claimed (emphasis added)." $" 11$

As part of this inquiry, a Court must first determine the standard of a person having ordinary skill in the art, known as a phosita, for the patented technology. ${ }^{12}$ Determining who a phosita is can vary depending upon the level of sophistication of technology. ${ }^{13}$ While this article does not discuss how a phosita is determined, this inquiry is very elaborate and attorneys and courts continuously struggle to determine who is a phosita for each and every case. Nonetheless, once a phosita has been determined, a Court begins the inquiry to determine whether a patent's claims are enabled throughout their full scope without requiring $\underline{\text { undue experimentation. }} .{ }^{14}$ It is the amount of experimentation required by a phosita, which is critical to an analysis of whether the claims meet this standard.

\section{a. UNDUE EXPERIMENTATION}

Determining whether an amount of experimentation amounts to undue experimentation is a factual inquiry and the factors for determining this analysis have been previously set forth by

\footnotetext{
${ }^{10}$ Invitrogen Corp. v. Clontech Labs. Inc., 429 F.3d 1052, 1070 (Fed. Cir. 2005).

${ }^{11} I$. at 1071 (citing In re Goodman, 11 F.3d 1046, 1050 (Fed. Cir. 1993)).

12 See John O. Tresansky, PHOSITA - The Ubiquitous and Enigmatic Person in Patent Law, 73 J. PAT. \& TRADEMARK OFF. SOC'Y 37 (1991).

${ }^{13}$ The person having ordinary skill in the art is a hypothetical person who is presumed to have known the relevant art at the time of the invention. Factors that may be considered in determining the level of ordinary skill in the art may include: (A) "type of problems encountered in the art;" (B) "prior art solutions to those problems;" (C) "rapidity with which innovations are made;" (D) "sophistication of the technology; and" (E) "educational level of active workers in the field. In a given case, every factor may not be present, and one or more factors may predominate." In re GPAC Inc., 57 F.3d 1573, 1579 (Fed. Cir. 1995); Custom Accessories, Inc. v. Jeffrey-Allan Indus., Inc., 807 F.2d 955, 962, (Fed. Cir. 1986); Env’t Designs, Ltd. V. Union Oil Co., 713 F.2d 693, 696, (Fed. Cir. 1983); MPEP, supra note 8 , at 2141.03 .

${ }^{14}$ Monsanto Co. v. Syngenta Seeds, 503 F.3d 1352 (Fed. Cir. 2007); In re Wright, 999 F.2d at 1561 (citing In re Vaeck, 947 F.2d at 495).
} 
the Federal Circuit in In re Wands. ${ }^{15}$ Known as the Wands factors, these factors balance the following in order to determine the amount of experimentation needed in order to satisfy the enablement requirement: (1) the quantity of experimentation necessary, (2) the amount of direction or guidance presented, (3) the presence or absence of working examples, (4) the nature of the invention, (5) the state of the prior art, (6) the relative skill of those in the art, (7) the predictability or unpredictability of the art, and (8) the breadth of the claims. ${ }^{16}$ The Wands factors are fact based and are not a bright line rule to determine what undue experimentation is for each and every case. ${ }^{17}$ Various court opinions have also weighed in on the types of experimentation that would amount to being "undue" 18 and would amount to a patent being invalid for lack of enablement. ${ }^{19}$ As part of this analysis, Courts look at Wands factor (7), which requires an inquiry into whether a patent is geared towards the "predictable arts" or the "unpredictable arts." 20 The type of art to which a patent is directed is critical towards the analysis of the amount of experimentation required to practice the invention set forth in the patent. ${ }^{21}$

\footnotetext{
${ }^{15}$ In re Wands, 858 F.2d 731, 737 (Fed. Cir. 1988).

${ }^{16} I d$.

${ }^{17} \mathrm{Id}$.

${ }^{18}$ Alza Corp. v. Andrx Pharms., L.L.C., 603 F.3d, 935 (Fed. Cir. 2010); Liebel -Flarsheim Co. v. Medrad, Inc., 481 F.3d 1371 (Fed. Cir. 2007).

${ }^{19} I d$.

${ }^{20}$ In re Wands, 858 F.2d at 737; See In re Vaeck, 947 F.2d at 496 (holding that where a claimed genus represents a diverse and relatively poorly understood group of microorganisms, the required level of disclosure will be greater than, for example, the disclosure of an invention involving a predictable factor such as a mechanical or electrical element); In re Fisher, 427 F.2d 833, 839 (C.C.P.A. 1970) (stating that "in cases involving predictable factors, such as mechanical or electrical elements, a single embodiment provides broad enablement in the sense that, once imagined, other embodiments can be made without difficulty and their performance characteristics predicted by resort to known scientific laws. In cases involving unpredictable factors, such as most chemical reactions and physiological activity, the scope of enablement obviously varies inversely with the degree of unpredictability of the factors involved.").

${ }^{21}$ In re Vaeck, 947 F.2d at 496; In re Fisher, 427 F.2d at 839.
} 


\section{b. The Predictable ARTS}

Predictable arts involve areas where there is high knowledge in the art and where general knowledge in the field is predictable. ${ }^{22,23}$ Examples of this include medical devices, the automotive industry, the mechanical arts, technologies that results in inventions in medical and electrical engineering, and other such industries. Courts have found that phositas in predictable arts are able to fill in the gaps even when certain embodiments of an invention have been inadequately disclosed or omitted from the specification or disclosure of a patent. ${ }^{24}$

In other words, a phosita in a predictable art is typically able to extrapolate the teachings of a single embodiment across the breadth of the claimed invention with a reasonable expectation of success. $^{25}$ Thus, for a predictable art, Courts have held that even a large amount of experimentation would not require "undue experimentation" as the effects of the experimentation would be predictable. This is in direct contrast to the "unpredictable arts" where Courts have

\footnotetext{
${ }^{22}$ The "predictability or lack thereof" in the art refers to the ability of one skilled in the art to extrapolate the disclosed or known results to the claimed invention. If one skilled in the art can readily anticipate the effect of a change within the subject matter to which the claimed invention pertains, then there is predictability in the art. On the other hand, if one skilled in the art cannot readily anticipate the effect of a change within the subject matter to which that claimed invention pertains, then there is lack of predictability in the art. Accordingly, what is known in the art provides evidence as to the question of predictability.

${ }^{23}$ The more that is known in the prior art about the nature of the invention, how to make, and how to use the invention, and the more predictable the art is, the less information needs to be explicitly stated in the specification. In contrast, if little is known in the prior art about the nature of the invention and the art is unpredictable, the specification would need more detail as to how to make and use the invention in order to be enabling. See, e.g., Chiron Corp. v. Genentech Inc., 363 F.3d 1247, 1254, 70 USPQ2d 1321, 1326 (Fed. Cir. 2004).

${ }^{24}$ See AK Steel Corp. v. Sollac \& Ugine, 344 F.3d 1234 (Fed. Cir. 2003) (holding that the artisan's knowledge of the prior art and routine experimentation can often fill gaps, interpolate between embodiments, and perhaps even extrapolate beyond the disclosed embodiments, depending upon the predictability of the art), Genentech, Inc. v. Novo Nordisk A/S, 108 F.3d 1361, 1366 (Fed.Cir.1997) (“[A] specification need not disclose what is well known in the art.").

${ }^{25}$ The scope of the required enablement varies inversely with the degree of predictability involved, but even in unpredictable arts, a disclosure of every operable species is not required. A single embodiment may provide broad enablement in cases involving predictable factors, such as mechanical or electrical elements. In re Vickers, 141 F.2d 522, 526-27 (C.C.P.A. 1944); In re Cook, 439 F.2d 730, 734 (C.C.P.A. 1971); MPEP $§ 2164.03$ (8 ${ }^{\text {th }}$ ed. Rev. 8, July 2010).
} 
held that inadequate disclosure in a patent specification results in patent claims being invalid for lack of enablement. ${ }^{26}$

\section{c. THE UnPREDICTABLE ARTS}

Courts have found the "unpredictable arts" to be arts which involve the chemical industry, the experimental sciences, and other such arts where the results are not easily predictable. ${ }^{27}$ Unpredictable arts are exactly how they sound - "unpredictable" - meaning that even phositas do not have reasonable success in predicting the effects in these arts and are not able to fill in the gaps when certain embodiments of an invention have been inadequately disclosed or omitted from the specification. ${ }^{28}$

To fully determine whether a claim in an unpredictable art is enabled, Courts look at the scope of the claims and make a determination whether the claims are enabled "throughout their full scope without requiring undue experimentation by those having ordinary skill in the art."29 This determination is especially significant in light of broad claim language, such as when claims are directed to multiple embodiments of an invention, but the specification of the patent only discloses one of the embodiments covered by the claims.

\footnotetext{
${ }^{26}$ In applications directed to inventions in arts where the results are unpredictable, the disclosure of a single species usually does not provide an adequate basis to support generic claims. In re Soll, 97 F.2d 623, 624 (C.C.P.A. 1938). In cases involving unpredictable factors, such as most chemical reactions and physiological activity, more may be required. In re Fisher, 427 F.2d at 839 (contrasting mechanical and electrical elements with chemical reactions and physiological activity). See also In re Wright, 999 F.2d at 1562; In re Vaeck, 947 F.2d at 496 . This is because it is not obvious from the disclosure of one species, what other species will work. MPEP § 2164.03.

${ }^{27}$ In re Fisher, 427 F.2d at 839 (contrasting mechanical and electrical elements with chemical reactions and physiological activity).

${ }_{28}^{28}$ In re Goodman, 11 F.3d 1046; Monsanto, 503 F.3d 1352; In re Wright, 999 F.2d at 1561 (citing In re Vaeck, 947 F.3d at 495).

${ }^{29}$ Invitrogen Corp. v. Clontech Labs. Inc., 429 F.3d 1052, 1070 (Fed. Cir. 2005).
} 
This issue was recently addressed by the Federal Circuit in Alza Corp. v. Andrx Pharms, $L L C .^{30}$ In Alza, the Federal Circuit concluded that the asserted method claims for treating primary Attention Deficit and Hyperactivity Disorder (“ADHD”) through a methylphenidate drug dosage form were invalid. ${ }^{31}$ The Alza Court found that Claim 1 of the asserted patent covered both osmotic and non-osmotic dosage forms. ${ }^{32}$ However, the specification only taught an osmotic dosage form and did not provide any disclosure that enabled a phosita to make a nonosmotic dosage form. ${ }^{33}$

Experts in Alza testified that it would take a phosita six months or more to develop a single non-osmotic dosage form ${ }^{34}$ and that even the Plaintiff in Alza failed for a few months to produce a non-osmotic dosage form. ${ }^{35}$ Thus, the Alza Court held that it required undue experimentation to develop the claimed invention and the claims were invalid for lack of enablement. ${ }^{36}$

Other Federal Circuit cases involved a similar analysis, where the Court found that the specification did not enable the full scope of the claims. In Libel-Flarsheim Co. v. Medrad, Inc., the asserted patent involved claims directed to both a jacket and jacketless injector, while the specification only disclosed a jacket injector, but not a jacketless injector. ${ }^{37}$ The LibelFlarsheim Court found that while jacket injector systems were enabled, the non-jacketless systems were not enabled, and thus, the broad claims that covered both embodiments were invalid for lack of enablement. ${ }^{38}$

\footnotetext{
${ }^{30}$ Alza Corp. v. Andrx Pharms, L.L.C., 603 F.3d 935 (Fed. Cir. 2010).

${ }^{31}$ Id. at 943 .

${ }^{32} I d$. at 938.

${ }^{33} I d$. at $939-40$.

${ }^{34} \mathrm{Id}$. at 942 .

${ }^{35}$ Alza Corp., 603 F.3d at 942.

${ }^{36} \mathrm{Id}$. at 943 .

${ }^{37}$ Libel-Flarsheim Co. v. Medrad, Inc., 481 F.3d 1371 (Fed. Cir. 2007)

${ }^{38} I d$.
} 
Additionally, the Court in Par Pharmaceuticals v. Roxane Labs., Inc. held that a patent related to stable flocculated suspensions of megestrol acetate was invalid for lack of enablement, as the Court concluded that the art of making stable flocculated suspensions of megestrol acetate was highly unpredictable. The Court found that despite three working examples, the inventors did not provide sufficient disclosure to enable the full scope of the claims. ${ }^{39}$

While such cases typically have been resolved due to a finding of lack of enablement, these cases do not provide any guidance to determine whether the claims are also simultaneously invalid as being obvious over the prior art. ${ }^{40}$ This is because once a Court finds the claims to be invalid for lack of enablement, the Court ends its analysis and no further guidance or opinion is provided as to any obviousness inquiry. Thus, patent practitioners, or litigators studying prior cases, have very little, if not zero, guidance from court opinions that hold claims to be simultaneously invalid for lack of enablement and also to be obvious over the prior art.

This presents a problem for practitioners, including both patent prosecutors and litigators, because practitioners are not provided with any legal analysis as to how to advance both arguments that claims are invalid for lack of enablement and also that the claims are obvious over the prior art. This is the dilemma that is explored below, as often arguments made to promote one's assertion that claims are not enabled cut against arguments that the claims are also obvious over the prior art.

\footnotetext{
${ }^{39}$ Par Pharms v. Roxane Labs., Inc., 253 Fed. App’x. 26, 2007 WL 3151692 (Fed. Cir. 2007).

${ }^{40}$ In many instances, claims are also invalid as being obvious. During case development and discovery, Plaintiffs and Defendants present all arguments. Typically, arguments are whittled down as parties file summary judgment briefs to dispose of "legal issues." Enablement is one such legal issue as compliance with the enablement requirement is an issue of law.
} 


\section{Brief OVerview OF the InHEREnt Problem Between EnABlement \& OBVIOUSNESS}

As noted above, once a court reaches a determination that the claims are invalid for lack of enablement, courts typically end their analysis and do not address whether claims are also simultaneously invalid as being obvious over the prior art. ${ }^{41}$ This is because once a court finds a single reason that a patent's claims are invalid, the court does not need to find another reason to invalidate the claims. ${ }^{42}$ However, when litigants attempt to invalidate claims, problems often arise when trying to harmonize the doctrines of enablement and obviousness, as arguments that are made in support of one doctrine often undermine the other one.

This problem was identified by the District Court of New Jersey in Eli Lilly \& Co. v. Actavis Elizabeth LLC (D.N.J. 2009), ${ }^{43}$ a decision which summarized the inherent problem between advancing both arguments for lack of enablement and obviousness:

Plaintiff emphasizes the differences between atomoxetine and the prior art for the purposes of refuting Defendants' obviousness argument, while at the same time asserting that the prior art and atomoxetine are in some ways similar in order to demonstrate enablement/utility. Defendants argue, then, that the Court must find the patent invalid as either obvious or not enabled. For example, if the Court determines that a person of ordinary skill in the art would be able to infer utility based upon the patent's specification, Defendants' enablement argument might fail, but its obviousness argument would presumably be bolstered.

As the Eli Lilly court correctly recognized, there is a problem between advancing one's arguments that claims are invalid for lack of enablement, while simultaneously arguing that claims are obvious over the prior art. This is a significant concern for defendants in patent litigation, as arguments made by defendants early on during discovery or during pre-trial

\footnotetext{
${ }^{41}$ Libel -Flarsheim, 481 F.3d 1371; Par Pharms, 253 Fed. App'x. 26.

${ }^{42}$ Once the court finds the claims to be invalid under $\S 112$, they are invalid and the court does not need to address whether the claims are also invalid under 35 U.S.C. $\$ 103$.

${ }^{43}$ Eli Lilly, 676 F.Supp.2d at 375 n. 19. 
procedures may be held to be limiting later on during trial. ${ }^{44}$ This problem is also significant in light of the type of art to which the patent relates, whether predictable or unpredictable, as it is often difficult to harmonize these arguments in both predictable and unpredictable arts.

a. Inherent Problem Between Enablement And Obviousness In The PREDICTABLE ARTS

In the domain of predictable arts, harmonizing the doctrines of enablement and obviousness is often problematic. For example, a patent may claim a type of sealing element to seal the air in an automotive brake so as to provide pressure to actuate a brake. The claim may be broad so as to cover all types of sealing elements, while the specification of the patent may only disclose a single embodiment, for example an O-ring, as an example of a sealing element.

In the predictable arts, Courts have held that the disclosure of a single embodiment can enable a broad claim. ${ }^{45}$ However, in a patent litigation, a defendant may argue that this claim is not enabled because it would require undue experimentation for a phosita to substitute other known sealing elements, such as a dynamic or hydraulic seal, for the disclosed sealing element (i.e. O-rings) because it would be readily apparent that other known elements (i.e., dynamic or hydraulic seals) would not work to seal the chamber in an automotive brake. However, once an argument is made that undue experimentation is required to make this substitution, it will be difficult for a defendant to simultaneously argue that it would be obvious to apply references that teach the other known elements (i.e. dynamic or hydraulic seals) to render obvious the broad claims directed to a sealing element.

\footnotetext{
${ }^{44}$ Litigators often try to nail down certain positions during discovery or during pre-trial procedures to advance their case.

${ }^{45}$ Libel-Flarsheim, 481 F.3d at 1378. See also Spectra-Physica, Inc. v. Coherent, Inc., 827 F.2d 1524, 1533 (Fed. Cir. 1987).
} 
This is because an argument made by the defendant that undue experimentation would be required to fully enable the scope of a claim for a sealing element cuts against the argument that it would involve routine experimentation and knowledge in lieu of prior art references to substitute other sealing elements for the disclosed sealing element, which is an argument the defendant would make when arguing that the claimed subject matter is obvious over the prior art. $^{46}$

Take for example a claim, which is so broad that it covers embodiments A-Z. If the patent specification only discloses embodiments A, B and C, then a defendant may argue that the specification does not fully support all embodiments supported by the claims and that it would require undue experimentation for a phosita to fully enable the scope of embodiments D-Z, thus, rendering the claim not enabled. However, once the defendant makes this argument, it will be very difficult for the defendant to simultaneously argue that it would be obvious to combine references $\mathrm{Q}^{1}$ and $\mathrm{Q}^{2}$ in an obviousness rejection because the defendant already argued that such a combination would require undue experimentation and thus would not be an obvious one to make.

b. Inherent Problem between Enablement And Obviousness IN The UNPREDICTABLE ARTS

In the unpredictable arts, attempting to harmonize arguments of enablement and obviousness is equally difficult. For example, take the patent directed to stable flocculated suspensions of megestrol acetate described in the Par Pharmaceuticals v. Roxane Labs. ${ }^{47}$ In Par Pharmaceuticals, the Defendant argued that the claims to stable flocculated suspensions were invalid for lack of enablement because not all of the stable flocculated suspensions covered by

\footnotetext{
${ }^{46}$ This is the conundrum recognized by Eli Lilly, 676 F.Supp.2d at 375 n.19.

${ }^{47}$ Par Pharms., 253 Fed. App'x. 26, 27. 
the claims were disclosed by the specification and thus the claims were broader than the specification. ${ }^{48}$ The defendant also argued that stable flocculated suspensions of megestrol acetate relate to an unpredictable art and that, in the field of unpredictable arts, a single embodiment typically does not reasonably enable the full scope of the claims. ${ }^{49}$ However, similar to the predictable arts, once a defendant argues that it would require undue experimentation to enable the full scope of the claims, it is then difficult for the defendant to simultaneously argue that prior art references also render the claims obvious.

In the context of experts and pre-trial development, the inability to make both arguments simultaneously without having one argument cut against the other is problematic and may lead to an expert being required to take contrary positions, which may affect his or her credibility at trial. $^{50}$

\section{PROBlems FACED BY EXPERTS IN SimUltaneOUSLY ARGUING THAT A PATENT IS BOTH INVALID AS NOT BEING ENABLED AND ALSO OBVIOUS}

\section{a. DRAFTING EXPERT REPORTS}

In a patent litigation, Courts typically require the parties to submit expert reports prior to conducting expert depositions. ${ }^{51}$ Expert reports are used to provide a framework of the expert's anticipated testimony and to serve as a guide to resolve the technical issues that are typical in a patent litigation. ${ }^{52}$

\footnotetext{
${ }^{48}$ Id at $30-31$.

${ }^{49}$ Id at 29.

${ }^{50}$ It is difficult for an expert to argue simultaneously that the claims are enabled and are also obvious without hampering his or her credibility with a judge or jury.

${ }^{51}$ MANUAL FOR COMPLEX LITIGATION, FOURTH $\S 11.48$ (2004)

${ }^{52}$ Experts are typically deposed on their expert reports in patent litigation.
} 
Expert reports are typically drafted to encompass all arguments and are comprehensive roadmaps of the information that an expert will testify to at his or her deposition and at trial. ${ }^{53}$ In fact, some jurisdictions require that experts be limited to discussion of only the topics and information listed in the expert report, unless rebuttal evidence is cited by an opposing expert. ${ }^{54}$

In the first round of expert reports, defendants typically provide affirmative expert reports that are focused upon the invalidity of the asserted patent(s). This may involve making arguments that patent claims are not enabled and also making arguments that patent claims are obvious over the prior art. ${ }^{55}$ As discussed above, this may often be problematic as it is difficult to mesh these two contrary arguments.

Using the above example of a sealing element, when drafting an expert report, an expert may assert that a claim is not enabled because it is broader than the disclosure in the specification and that it would not be possible to substitute a valve for a sealing element because of the configuration of the brake, so that certain types of valves which are covered by the claims cannot be used.

In the same report, the expert may also argue that it would be obvious to substitute the same known prior art valves to make an argument that the claims are obvious over the same known prior art. The fact that the expert is taking two contrary positions will most likely discredit the expert and may end up damaging the expert's credibility.

\footnotetext{
${ }^{53}$ The first key work product of the expert witness is typically the expert report. The Federal Rules of Civil Procedure (the Rules) mandate that all testifying experts submit written expert reports detailing opinions they will express at trial. Rule 26 includes strict requirements for the reports, and an expert can be barred from testifying if the required disclosures are not made in a timely and substantive manner. See John L. North \& Laura Fahey Fritts, Exploring expertise: effective use of expert witnesses in patent litigation, IP VALUE (2005) http://www.sutherland.com/files/Publication/c488e565-d90d-4196-a449db94bb91c300/Presentation/PublicationAttachment/cb411dab-72da-405b-a7f5a10c0a2fa153/IP05\%20Sutherland.pdf.

${ }^{54} \mathrm{Id}$.

${ }^{55}$ Arguments that a patent is not enabled and also obvious over the prior art are both invalidity arguments that are made in expert reports focused on invalidity.
} 
Skilled attorneys are often able to use an expert's report during an expert deposition in order to box the expert into taking a certain position. However, this position may ultimately not be the same position the expert ends up taking at trial and ultimately, the arguments made by an expert during his or her expert report or deposition testimony may be disadvantageous to the defendant.

b. ARguing that a PATENT is Both INVALID AS NOT BEING ENABLED AND OBVious DURING DEPOSITIONS AND TRIAL

During a deposition, an expert may testify that he or she believes that the claims are invalid for lack of enablement and may take a position that it would not be obvious to substitute a valve for a sealing element, as in the example described above. ${ }^{56}$

This may be problematic, as during expert discovery, or at a later point in the litigation, new facts may arise, such as a new prior art reference being found that provides a strong working example and a motivation to substitute the valve for a sealing element. Also, the expert may change his or her position in light of any new report or evidence provided.

Thus it is problematic for an expert to take contrary positions that a patent is both lacking enablement and also simultaneously being obvious. Taking both positions simultaneously may have the credibility of the expert compromised at trial.

\section{SUGGESTIONS}

As a result, it is difficult for a single expert to advance both positions that (1) a patent is invalid for having its claims lack enablement, and (2) that claims are invalid for being obvious over the prior art.

\footnotetext{
${ }^{56}$ See supra note 57.
} 
In light of these difficulties, it is recommended that litigators continuously analyze their best arguments and carefully prepare experts when putting forth arguments that the claims lack enablement and are also obvious over the prior art. It is important for litigators to prepare experts and ensure that they are wary that when arguing that claims lack enablement, these arguments may cut against future arguments that the claims are obvious over the prior art.

It is also suggested that that parties retain multiple experts to solve this dilemma. One expert may put forward an argument that a patent is invalid for lack of enablement, while the other expert may argue that the patent is obvious. However, there are also drawbacks to having more than one expert. First, it is more expensive for a party to retain multiple experts. Second, having multiple experts that take conflicting positions for the same defendant may ruin the credibility of both of the defendant's experts.

It is thus recommended that prior to asserting both lack of enablement and obviousness arguments, defendants should carefully consider the strengths and weaknesses of each argument, in order to adequately prepare experts for trial. 